\title{
The Refugee Journey as Rites of Passage \\ In Alan Gratz's Refugee
}

\author{
Nihal A. Adel Zaki*
}

nehal.adel@minia.edu.eg

\begin{abstract}
This paper examines the refugee journey from displacement to emplacement in Alan Gratz's Refugee. Using the theory of rites of passage, as a starting point, it studies the life-changing experiences of the three refugee protagonists in three different stages: the life in their motherlands before their movement into another destination, the intermediary or liminal stage where their journey begins across borders and the final stage where they reintegrate into the host country. Moreover, the study attempts to provide a further analytical ground by adding spatial as well as psychological dimensions to the protagonists' rites of passage via integrating two complementary theoretical concepts: non-place and resilience. In doing so, it offers new insight into the hardships and trauma endured by the protagonists in every stage and how they come up with resilience strategies that help them survive the constant transitions from one phase to another. Altogether, by rethinking the refugee experience as rites of passage, a more comprehensive picture of refugees' departure, journey, and arrival can be addressed.
\end{abstract}

Keywords: Refugees, Rites of Passages, Non-place, Resilience, Liminality.

* English Dept., Faculty of Al-Alsun( language), Minia University. 


\section{Introduction}

Migration is one of the pre-existent human activities that have always been part of people's behavior all over the world. It refers to the "process of social change where an individual, alone or accompanied by others, because of one or more reasons of economic betterment, political upheaval, education or other purposes, leaves one geographical area for prolonged stay or permanent settlement in another geographical area" (Bhugra 129). For refugees, however, migration is a life-crisis experience as in the pre- migration stage; they are obliged to leave their homelands in order to flee war and harassment. Moreover, the journey to the new host land is mostly a prolonged and an arduous one. Further, the post-migration stage, where they apply for asylum, is highly marked by loss of family members and identity crisis. Due to the global increasing number of refugees in the recent decades, a broad spectrum of fiction that tackles refugee issues has been published. Most of such fiction exposes the escape from violence and war in the motherland as well as the challenges of acculturation and adaptation in the host land. Refugee, however, traces the three phases of refugee journey. In an attempt to theorize the refugee protagonists' threefold-stage journey, the theory of rites of passage is adopted in this study.

The remarkable traditional theory of rites of passage was first coined by the French folklorist Arnold van Gennep (18731957) in his 1909 Les Rites du Passage to refer to all existing 
ceremonious acts that accompany a person's life crises or any transition from one status to another such as weddings, graduations, parenthood, puberty, birth and death (3). He divides such ritual passage into three successive stages: first, a pre-liminal stage, where rites of separation occur; second, a liminal stage, where rites of transition occurs; and finally a post-liminal stage, where the rites of "incorporation into the new world" are performed (21). These rituals mark transformations within any society. And "it is the function of rites of passage to reduce their harmful effects" (van Gennep 13).

Van Gennep refers to rites of initiation as the most typical rite of passage (67). In the rite of initiation into adolescence, for example, the transformation is markedly evident. During the separation stage, the child separates from his social group; this entails his death as a child, as his childhood has successfully come to an end. In the liminal phase, the subject, between childhood and adolescence, has to be tested to verify that he is able to perform his duties as an adult. Passing this test indicates the beginning of the post-liminal stage where he reincorporates into the social group that celebrates his new birth as an adolescent. In the context of refugee literature, rites of passage would be a useful notion, but not inevitably in its conventional meaning. In this paper, van Gennep's threefold schema is used to examine how the three main characters' separation phase is characterized by a metaphorical death. In order to reintegrate, 
they must first experience a traumatic detachment from their homelands; they literally have to die as a legal citizens. Death is followed by a rebirth: the refugees have died, just to be reborn once more as legal citizens in the host land. The third stage, postliminality, celebrates this new position.

Unfortunately, Arnold van Gennep did not witness the warm reception that his book has received in the English-speaking world. Since the release of the English-language publication of Les Rites du Passage in 1960, and three years after van Gennep's passing away, his theory began to be more influential all over the world (Thomassen, Liminality and the Modern 71). Motivated by van Gennep's work, the British anthropologist Victor Turner rediscovers and develops van Gennep's theory of ritual passage. Turner is not simply different from van Gennep in his application of the three phases of rites of passage to the individual or social group; rather, he elucidates that the stages of ritual passage are to be more broadly applied in larger-scale society. They, further, include an "entry into a new achieved status, whether this be a political office or membership of an exclusive club or secret society" (Turner, The Forest of Symbols 95). Moreover, he gives specific importance to the liminal stage, the intermedial stage of van Gennep's theory. He finds that during the liminal stage, the subject of passage is in a "betwixt and between" state, a threshold from which a new social state or identity may come to existence (The Forest of Symbols 95). Consequently, he may change from 
his previous state into something different when he is reintegrated back in the social structure. In this respect, liminality, for Turner, cannot be a place one stays, but rather a space one moves through on his way back to integrate into social group. In this study, Turner's concept of liminality is applied to depict the period when the three refugee protagonists are caught between and within borders. Refugees themselves are referred to as liminal subjects, whereas between and within borders are liminal spaces.

Since the theory of rites of passages has been expanded in this study to include the psychological and spatial passage of the refugee protagonists from their homelands to host lands, its analytical perspective needs to be supported by other complementary theoretical concepts. Two such theories can be identified: non-place and resilience. These theories become mostly important particularly once refugees' journey is analyzed as stages in rites of passage. The first theory elaborates the spatial experience of the protagonists' transitions, whereas the latter examines their psychological resistance during their journeys.

Places that "cannot be defined as relational, or historical, or concerned with identity" (Augé 77-78) are known as nonplaces, a phrase coined by the French anthropologist Marc Augé to describe such spaces that are in-between others. Augé's theory comes to light in his 1995 influential work Non-Places: Introduction to an Anthropology of Supermodernity in which he elucidates how the spaces of passage such as the hotel, airport, 
supermarket, bus station and motorway are non-places. Nonplaces are in opposition to places which are "relational, historical, and concerned with identity" (Augé 77-78). As non-place explains how places can be seen as a place of transit, the borders where the protagonists pass through during their liminal phases are investigated in this study as non-places.

Another significant theoretical concept employed in this study is resilience that is particularly studied "in relation to transitions" (Tusaie and Dyer 3). Resilience literature as a theory in literary criticism has not yet existed; nevertheless, the construct of resilience as theorized in psychological literature "extends from the 1800's to the present" (Tusaie and Dyer 3). The American Psychological Association refers to resilience as "the process of adapting well in the face of adversity, trauma, tragedy, threats or even significant sources of stress." Resilient individuals, thereby, are able to cope with living in the face of life-crises and lifechanging experiences. "Resilience, therefore, emphasizes the strengths that the people have, rather than their vulnerability, through exploring the coping strategies that they exhibit" (Mlambo 39). In Refugee, this perception goes beyond the idea of coping and adaptation by including the resistance and transformation of the protagonists.

Refugee is a 2017 historical tripartite narrative written by Alan Michael Gratz, the bestselling American novelist of numerous narratives for young adults. Written from the third- 
person viewpoint, using the three young adult main characters as focalizers, this piece of fiction chronicles the experiences of three separate young refugees fleeing their countries of origin during different times and places: 1939 Germany, 1994 Cuba and 2015 Syria. Both temporal and spatial settings of the novel are not real; however, they are reminiscent of actual times and places such as Kristallnacht, 1994 Havana Riots and 2015 Syrian Civil War. For more than a year, the book remained on the list of New York Times bestseller. Moreover, it received a number of prizes among them the Cybils Middle Grade Fiction Award and a Malka Penn Award for Human Rights Honor. Further, it was selected as a Global Read Aloud Book in 2018 (Gratz, "About Me"). One of the remarkable aspects of this narrative is that its structure can be considered as a reenactment of the rites of passage: separation, liminality, and incorporation. In other words, it comprises three central zones through which the literary characters move: the zone of displacement (motherland), the zone of transition (between and on borders) and the zone of emplacement (host land).

\section{The Protagonists' Pre-liminal or Separation Stages:}

Alan Gratz's Refugee is a story full of traumatic and life-crisis events varying from displacement to adversity. Since the outset of the narrative Josef, Isabel and Mahmoud come close to their rites of separation or the pre-liminal stage by being isolated from "their previous social statuses" in their countries where they were legal citizens (Turner, "Liminal to Liminoid" 57). This stage 
"comprises symbolic behavior signifying the detachment of the individual or group either from an earlier fixed point in the social structure or a set of cultural conditions" (Turner, The Forest of Symbols 94). For a twelve-year-old Josef Landau, who is about to celebrate his passage into adulthood, the pre-liminal stage takes place in Adolf Hitler's Germany, where he lives with his parents and his sister, Ruthie. Already at the beginning of the storyline, Gratz situates his readers in the focal point of events and directly shows the brutality of the Nazis against the Jewish citizens. On Kristallnacht, the incident of intensive cruelty by Nazis all through Germany and Austria against the Jews, Nazi troops go through and destroy the contents of the house of Josef's family, frightening Josef, beating his father and pulling him to Dachau concentration camp. Before this incident, Josef was just a child not aware of the violence that was occurring around him. In spite of the fact that Josef is fairly alert to the brutality of the Nazi regime, his separation stage does not take place before he is confronted with the Nazis who create chaos and separate him from the life he is accustomed to. Although Josef is inside his own home, the time spent with the Nazis separates him from his previous life as he is traumatized and victimized. Consequently, the family's social status is permanently turned upside down; "The Nazis hadn't said it with words, but the message was clear: Josef and his family weren't wanted in Germany anymore" (Gratz, Refugee 5). Moreover, when the Nazis declare that they 
are not "'real" Germans" (Gratz, Refugee 18) and consider the father's practicing of law as a "crime against the German people" (Gratz, Refugee 3) this intrinsically detaches the family from their own cultural state. Josef is proud of being a German, and yet the authoritarian regime attempts to eradicate his German Jewish identity. He is ridiculed in school for being a Jewish, feeling 'the humiliation of being talked about like he was an animal. A specimen. Something subhuman" (Gratz, Refugee 20). His homeland, which was a place that is "formed by individual identities, through complicities of language, local references, the unformulated rules of living know-how” (Augé 101), becomes a non-place in his eyes as the "space in which [he] still live[s] ... is no longer the place where [he] used to live" (Augé 56). He departs both structurally and psychologically from his own cultural identity even though he is still in a place that is ironically called motherland. His sense of place in Germany is, therefore, shattered into pieces.

Feeling the sense of being in a non-place is Josef's moment of crises that transforms his life. Such transformation leads Josef and his family to leave Germany to seek refuge in Cuba. They are, therefore, alienated and detached from an "earlier fixed point" to go through geographical and social boundaries. This resonates with Turner's remark that, "[t]he passage from one social status to another is often accompanied by a parallel passage in space, a geographical movement from one place to another. This may take 
the form of a mere opening of doors or the literal crossing of a threshold which separates two distinct areas" ("Liminal to Liminoid" 58). In the same way, Josef embarks on a journey of crossing borders; such spatial passage pinpoints his transition from the pre-liminal stage to the liminal one.

Similar to Josef, Gratz introduces the eleven-year-old Isabel in the middle of a community that suffers from the trauma of political upheaval. Isabel enters the separation stage when a rebellion starts in Havana because of the constant food shortages and President Fidel Castro's repressive government. Finding that her father, Gerlado is beaten and about to be arrested by the police officers, Isabel runs in front of the police in order to protect him, showing the maturity and responsibility of someone much older. Her action agrees with Turner's findings that during the preliminal stage, participants make "symbolic behavior - especially symbols of reversal or inversion of secular things, relationships, and processes -which represents [their] detachment" ("Liminal to Liminoid" 57). Isabel performs an "inversion" of relationships in her separation stage; instead of being the child who has to be protected, she seeks out danger to protect her father who is about to be "thrown into jail and never heard from again" (Gratz, Refugee 26). Moreover, she shows much maturity when she organizes for her family to flee to Miami, exchanging her beloved trumpet for the gasoline needed for the trip. 
Isabel's eagerness to give up her trumpet, which symbolizes her attachment to her country of origin through music, denotes that she loses any sense of place in Havana. Sharma succinctly remarks, "[G]etting lost in space is only one experience of the non-place" (129). Feeling the meaningless of non-place, Isabel decides to start a new life in "a place where her father wouldn't be beaten or arrested. Or run away" and where there "is food ... And freedom. And work" (Gratz, Refugee 44). Her first option is The United States of America where she believes that her dreams can be fulfilled.

Like Isabel and Josef, the twelve-year-old Mahmoud Bishara's separation stage starts when he experiences the trauma of pre-departure, being taken away from his ordinary life in the Syrian civil war in 2015. Before this time, Syria has been an attractive peaceful country, until 2011 came and the Arab Spring swept through Syria (Gratz, Refugee 14). The situation rapidly changed to an aggressive and traumatic one when the President of Syria, Bashar al-Assad, declared a war against people who opposed him, making them "disappear" (Gratz, Refugee 14). According to van Gennep this "declaration of war" is considered one of the rituals of the separation phase (39) in which participants move "from a period of peace as against one of war" (Turner, "Liminal to Liminoid" 57). Living in a war-torn country, Mahmoud experiences a drastic transformation in his character; he becomes "nervous. Twitchy. Paranoid" (Gratz, Refugee 8). 
Moreover, he experiences such a startling feeling of separation that he becomes invisible and befriends no one (Gratz, Refugee 12). Further, his sense of detachment is intensified when his apartment is attacked and destroyed by a missile. For Mahmoud, such an attack on his house is "not just an attack on material structures, but an attack on place - on meaning" (Cresswell 169). Therefore, his space symbolically transforms to a non-place where any sense of meaning is ruined.

Resembling Isabel, Mahmoud encounters an "inversion" of relationships during his separation stage. In spite of his young age, he tries to protect his younger brother, finding a new way to safely reach their house from the school every day. In this way, they are able to move away from the rebels or the Syrian defense forces, and hide from missiles if required. Moreover, he acts as an adult in this time of crisis when his house explodes, making sure that his brother and infant sister are harmless. Being homeless, Mahmoud and his family decide to depart their country of origin and commence the journey of searching for a new place where they can call home.

Although the three protagonists are brought up in very diverse time and places, Gratz highlights parallels between their pre-liminal stages and resilience. All three start their pre-liminal phases when they experience the trauma of wars and great violations of human rights in their homelands. They resiliently face such life-threatening circumstances by leaving their countries 
of origin and seeking refuge in other countries. In doing so, they find their resilience in "avoid[ing] a perceived threat or danger" (Neenan 31), "maintaining a sense of hope" (Birkholm 193) and "creating new possibilities" for life (103). In avoiding the wars and riots in their homelands and hopping to find a place of living to lead a meaningful life against all the trauma they have encountered, they end up their suffering in this stage of separation. In Birkholm's words, their rites of passage "are used as a means of supporting [their resilience] as they embark on a new phase of life" (21). The greatest challenge, however, arises by embarking on the upcoming stage: the liminal stage.

\section{The Protagonists' Liminal Stages:}

Being structurally, spatially and psychologically separated from their own countries and not yet integrated into their host lands, the three protagonists' liminal phases become more pronounced. They geographically enter into turner's "neither here nor there" (Turner, The Ritual Process 95) spaces where temporal and spatial borders exist and where they become "liminal, being betwixt and between home and host" (Thomassen, "The Uses and Meanings of Liminality" 19). Moreover, they have neither the characteristics nor social positions of the separation or those of the incorporation phase; In Turner's word, they are "a limbo of statuslessness" (The Ritual Process 97). As asylum-seekers who seek shelter from the harassment and violations of human rights in their homelands, they find themselves in uncertain or vague 
conditions in which they have not yet been legally classified or recognized as refugees. This is much similar to Turner's description of the "passenger," who exists in the liminal space, as someone who is "at once no longer classified and not yet classified" (Turner, The Forest of Symbols 96). Likewise, the three protagonists are threatened of being stuck in liminality because their "passage from one country to another ... [is] accompanied by various formalities" (van Gennep 15). Such formalities can be perceived as a signifier for the status of liminality that non-places like border zones force upon Joseph, Isabel and Mahmoud. It is worth mentioning that a person's connection to the border as a non-place is "contractual," and the non-place's regulations are clear and defined (Augé 101). When a person exists in a non-place, he enters in that space that is formulated by specific regulations. What's more, "the contract always relates to the individual identity of the contracting party" (Augé 101). In the case Josef, Isabel and Mahmoud's contract with the other party, their status as asylum seekers limits their access to the desired destinations. Waiting for many days on the ship, Josef and the other refugee passengers are told by the Cuban border guards (the contracting party) that the asylum for Jewish refugees is no longer allowed. They are ordered to leave the Cuban water to sail north to the U.S.A that refuses their entry too. The same can be said in Isabel's story that shows how the U.S.A government as a contracting party has "different requirements in 
this area" (Augé 102). The American authority formulates new rules for crossing its borders that the Cubans call "Wet Foot, Dry Foot" (Gratz, Refugee 41). If Cuban refugees are able to reach the beach, they can stay and will be granted asylum; however, if they are caught in water, they are either sent back to Cuba or face prison sentence (Gratz, Refugee 41). To cross the border is to put foot on the territory. Mahmoud, on the other hand, move through many border zones in order to make it to Germany that has a reputation of being a safe place with flexible asylum procedures. Every time he enters a threshold, he is subjected to both physical and psychological trauma because he can only be in the space of a non-place temporarily. Such temporality generates a feeling of confusion and discontinuity towards that place and the relationship he has to the persons who live in that place (Augé 84). That is why Mahmoud have always reservations about those people living in every space he crosses. Thus, all the three literary characters do not have "the unformulated rules of living knowhow" (Augé 101) in their space, because the authority lies in the hands of the contracting party that suspends their ordinary life whilst they are waiting for a decision of passage on borders. In this way, neither the host nor the home countries would like them to get access to their borders, the matter that increases their feelings social exclusion and insecurity.

The uncertainty of official status and long waiting times within the liminal stage is commonly followed by a sense of 
passivity and inferiority. Turner relates liminality to "marginality and "inferiority" (Turner, The Ritual Process 130). He refers to the subjects who find themselves in the non-status zone as those who are "normally passive or humble; they must obey their instructors implicitly, and accept arbitrary punishment without complaint" (Turner, The Ritual Process 95). These negative connotations of liminality are similar to those of Josef and Mahmoud who exist on the margins of social structures. As soon as Josef boards the MS St. Louis, he and his other comrades on the ship are described as "Jewish rats" by a Nazi official, Otto Schiendick (Gratz, Refugee 97). This explicit humiliation causes Josef's "frustration and embarrassment at his helplessness" and passivity (Gratz, Refugee 97). Moreover, it encourages the Nazi soldiers to be more aggressive; for example, Schiendick as well as the other Nazi officers turns the Landau family's cabin upside down. They make unreasonably brutal acts like destroying everything in the cabin and tearing off the head of Ruthie's doll, while Josef and his family are unable to lift a finger. However, the most terrible indication of their humiliation and inferiority occurs when they are obliged to stay in the ship for many days to be denied entrance into Cuba and also into the U.S.A., although their return to Germany means their imminent death. Similarly, Mahmoud and his family face inferiority and vulnerability, as they are ruthlessly exploited by many people who try to take advantage of their passivity and weakness. They are charged large 
amount of money for sleeping in an abandoned shopping center (a no-place) that is not typical to life by any means, and are convinced to purchase life vests that turn out to be fake. Moreover, they are robbed at gunpoint by a taxi driver, leaving them stranded when they are at their most weakness. That is why "Mahnoud would not forget that feeling of paralyzing terror, of powerlessness" (Gratz, Refugee 249). Further, when Mahmoud and his family travel to Hungary, they are prevented from entering the country. They are treated like those liminal entities who "have nothing," who lack all the rights relating to "property, goods, and services" (Turner, The Ritual Process 98-99, emphasis original). The officers shoot tear-gas, imprison and hit Mahmoud's family and the other refugee passengers, throwing them foodstuff as if they were dogs in the street, 'We don't want your filth here ... You're all parasites!" (Gratz, Refugee 267). Finally, the family is sent to immigrant camps, a non-place that Mahmoud describes as a prison.

Thus, those who go through the liminal state find themselves in an ongoing state of suffering and anxiety. In his explanation of the liminal status, Turner stresses that the characteristics of the liminal personae or "threshold people" are ambiguous, expressed by a range of different symbols related to suffering, death, "being in the womb," "darkness" and "wilderness," among others ( Turner, The Ritual Process 95). In Gratz's three stories, the ocean and the sea come to symbolize the 
refugee protagonists' despair and suffering. All three literary characters cross either the sea or ocean, and for each of them the sea/ocean denotes ambiguity and danger as they are not sure whether they will make it to safety or not. In Josef's narrative, his father tries to kill himself by throwing himself in water and drowning. For Isabel, a hole in her raft causes a leak and she as well as the other passengers is obliged to continually bail water out of it so as to remain floating. Moreover, her friend, Ivan does not survive a shark attack and his body is abandoned in the water. Shedding bitter tears, Isabel "wished she was dead too ... so they would put her into the water with him. So, she could keep him company in the deep" (Gratz, Refugee 300). Mahmoud witnesses a hazardous sea-passage from Turkey to Greece, in which he exerts great efforts to stay alive along with his mother in the sea while the greater part of the passengers is drowned.

Such traumatic experiences seem intolerable and one cannot help to wonder how it is probable for anyone to stay alive in such tormenting conditions. Gratz, however, manages to show how his characters are able to cope with such odds and adversity by adopting certain survival skills and resilient strategies. He clarifies how the protagonists' marginal status as asylum seekers pushes them to maintain optimism and resistance during their liminal phases. In fact, optimism is identified as one of the most important attributes of resilience (The American Psychological Association); it pinpoints how, despite adversity, people challenge 
the harrowing experiences and resiliently continue to go on. Gratz uses boats, which act as non-places, in the three narratives to symbolize such optimism and resistance and to create more possibilities to exit this non-place of transition and reenter a place of living. For Josef and his parents, the ship symbolizes a means of fleeing the Nazis and a way to turn over a new leaf. It makes them in high spirit during the journey because it keeps them away from the terror and violence in their homeland. The raft that Isabel uses to flee Havana represents her optimism all through her moments of liminality and uncertainty. Although it is described in the narrative as a "sinking coffin" (Gratz, Refugee 101), Isabel never discard the hope that it is her only way to start a new life along her family in the U.S.A. likewise, Mahmoud travels by boat that happens to sink in arduous weather conditions, and he as well as his family literally resists to stay floating. His mother does her best to keep her baby, Hana above the sea, and when another boat appears, Mahmoud suggests that they take Hana to safety. Such boat symbolizes not only an opportunity for his baby sister to lead a good life, but a survival motivator that encourages Mahmoud to resist death and take the survival decision for his sister.

In such liminal moments, people may have a feeling of affinity and connection with others that derives from shared experiences, mutual understandings and social equality. They represent communitas, the word Turner uses to explain "spontaneous immediate and concrete relatedness, typical of 
bonds formed between people in the middle liminal stage of a rite of passage" (Bowie 153). Moreover, the American Psychological Association stresses that the experience of community and "prioritiz[ing] relationships," in which a person connects with compassionate and thoughtful people that can remind him that he is not in his own in the midst of trauma, "support the skill of resilience." In fact, the relationship which grows among refugees during this phase of their journey is natural and these people often have a combination of mutual feelings, understanding and connection. Josef is part of the communitas aboard the ship where he experiences a parallel feeling of displacement with his parents, sister and other Jewish refugee passengers. He finds his resilience in reconnecting to his Jewish culture, as the passengers of the MS St. Louis are entirely Jewish. In another sense, a further state of communitas emerges when he and Ruthie are able to make new friendship and regain some of their purity and childhood as they befriend and play with two girls. In this way, he tries to replace the meaningless of non-place with vigorous movements. Josef laments that he has not laughed or played like this since a long time and hopes he can remain on the ship everlastingly. For the first time since the rise of Nazism, he is able to behave as ordinary child.

Moreover, when Josef becomes thirteen-years old on the ship, he gets the opportunity to celebrate his Bar Mitzvah, a Jewish rite denoting his passage into maturity, with the 
participation of other passengers and the crew of the MS St. Louis. As German Jews have been anxious to publicly gather together since Kristallnacht, this celebration is the first time in which Josef is capable of connecting explicitly with his Jewish culture. He begins to remember some reminiscences of his customs and traditions and has the chance to recite from the Torah. Thus, Communitas comes out in the nonexistence of sociopolitical structures within the liminal phase. It is not necessary for Josef to be in Germany to stay connected to his Jewish identity; what is only required is his communitas. In the same way, Isabel and other passengers shares aspects of communitas because they are in the same boat. Distancing themselves from their homeland and culture, creates a homogenization of status and a deep feeling of communitas. They support each other and cooperate in bailing water all the time during their journey to the extent that they are forced to swim interchangeably beside the raft instead of being inside it to reduce the weight that the raft has to bear.

Mahmoud, on the other hand, while moving from the space of non-place to another with his family, he is befogged by his own solitude. However, as long as Augé's non-place is a space of solitude and the only sort of identity that exists in a non-place is the shared identity of being a passenger (Augé 103), Mahmoud and the other refugees have a shared "passenger" identity in their crossing of borders as they have the identical status. Facing the possibility of remaining in liminality brings these refugee 
passengers together both literally and symbolically. Once Mahmoud begins to take an action against the border authorities, they follow him and create a "community resilience" in which they "unite and collaborate toward a shared goal or objective" (Moore). They come closer to transform their shared identity to communitas that lets them experience community strength and make an action that "underpins[s] resilience-promoting factors" (Moore). Turner's concept of communitas becomes helpful to understand how being among and with each other is something that support refugees in their shared sense of indefinite liminality. Such social support and community resilience, which come in the form of communitas, have been described as an important factor in several domains of resilience (Tusaie and Dyer 4). Moreover, it creates the opportunity of transforming the protagonists from nonplace spaces, which is devoid of significant social life, to an "existential space" in which existential purpose of existence come into view (Augé 80).

Though the liminal stage is a major cause of life stress, it opens up the opportunity for its participants to change. For Turner, liminality creates a space of being re-shaped or "fashioned a new" in which the liminal beings acquire "additional powers to enable them to cope with their new station in life" (The Ritual Process 95). Refugee assumes that there is something to be indicated about how the refugee protagonists acquire a new role and resist the state of liminality and its related stress and trauma. 
Feeling stressed and disappointed in finding a place of shelter, Josef becomes involved an act of resistance that can make his life better; however, it contradicts with the rule of non-place. He agrees to assist Pronzer, a Jewish passenger on the MS St.Louis, in seizing the ship hostage and direct it towards the U.S.A. borders. This collective act of resistance echoes Turner's remark that communitas "incite men to action as well as to thought" to reach the possible solution to the problem (The Ritual Process 129). This is, in fact, called "problem-focused coping" in which a person resiliently tries to alter or eliminate any stressful situation (Lazarus and Folkman 44). Josef's adoption of problem-focused coping approach transforms him from a passive person, who is used to hide to avoid being arrested by the Nazis, to a man of action. Moreover, in spite of being young, he is obliged to grownup quickly and to bear the responsibility of his family, which his traumatized father is not equipped to fulfill anymore. His liminal experience "shape[s] [his] personality, focus[es] [his] mind and experience, and foreground[s] [his] human agency (Thomassen, "The Uses and Meanings of Liminality" 14). Subsequently, Josef is the man of the family who shall adopt all the measures. Same would apply to Isabel whose liminality transforms her, forcing her to mature fast and to bear more responsibilities. It is she who saves one of the passengers of the raft from drowning, assist in bailing the sinking raft, and carrying her new-born brother to safety in Miami. Similarly, Mahmoud's nature entirely changes 
within his liminal stage. He undergoes a process "of growth, transformation, and the reformulation of old elements in new elements" (Turner, The Ritual Process 99). During the shipwreck, Mahmoud shows much maturity when he takes the critical decision of giving his baby sister to a stranger woman in a passing boat lest she drowns. Further, like Josef, he decides to adopt the problem-focused coping strategy and take a resistant action to end up his liminality; the matter that transforms him from an invisible to a visible person. Realizing that refugees have to be visible, he leaves the Hungarian detention center and leads the journey of the imprisoned refugees on a 12-hour walk to Austria. He understands that being under the observation of UN officers, the Hungarian authority will not have the courage to arrest them. This action attracts the media all over the world, which serves as a kind of resistance against the rules of non-place. Accordingly, they are welcomed on the Austrian border and provided with supplies. It becomes clear, then, that the liminal zone and non-place are in fact the spaces that open the door for transformation and problemfocused copping which facilitate resilience and positive adaptation that help the three refugee protagonists get better and attain new spirit and role.

Rites of passage are usually understood as having a further step forward that should be fulfilled before entering into the subsequent step and finally to the endpoint of the ritual passage. Liminality, however, can be an endpoint rather than a temporary 
and in-between stage. Turner argues that "a liminal state may become fixed, referring to a situation in which the suspended character of social life takes on a more permanent character" (Thomassen, "The Uses and Meanings of Liminality" 15). This notion of permanent liminality are tackled comprehensively by the sociologist scholar Arpad Szakolczai who argues that "liminality becomes permanent condition when any of the three phases in this sequence become frozen, as if a film stopped at a particular frame" (220). This is exactly what happens to Josef who is entrapped in a status of permanent liminality without being capable of going further. No sooner had Josef, his mother and sister settled in France than the Nazis invaded it, taking them into custody. Thus, their present place in France bears a resemblance to the negative sides from their past place in Germany. Augé elaborates this as their "history is on [their] heels, following [them] like ... shadows, like death" (26). Josef's mother is obliged by a sadist German soldier to trade her jewelry for the liberty of either Josef or Ruthie. Josef, the one responsible for the family, takes the decision and asks the officers to spare his sister. Josef is not seen in the narrative anymore. Being caught in a state of neither-this-nor-that, he is unable to make it to safety and complete the rites of incorporation. Thereby, his spatial, structural and temporal state of liminality becomes fixed. 


\section{The Protagonists' Post- Liminal or Incorporation Stages}

The final stage of the three stages of rites of passage is incorporation or post-liminality. In the case of the three refugee protagonists' journeys, only Isabel and Mahmoud's transitions have accomplished and gone smoothly. Their incorporation and transition occur when they make the "right" contract (Augé 102) with the contracting party of the non-place that allows them to exit it to enter the anthropological place where they are identified as members the society and greeted in that society with a new status, "stamped by the formative experience" (Thomassen, "The Uses and Meanings of Liminality" 22). Taking the necessary steps to be properly integrated into their new countries of residence, they receive asylum and begin to "unite [themselves] with [the] new world" where they are given the official status as refugees (van Gennep 20).

Crossing the U.S.A. borders, Isabel feels both overwhelmed with the outlook of resettlement and enthusiastic for the opportunity of living in a new destination. However, the realities of acculturation or the process of adopting the culture of the host land challenges her resilience. Once Isabel's status is completed, she starts to be worried about her culture and feel acculturative stress over the loss of her cultural identity. She resiliently chooses to adopt Berry's strategy of integration in which she is keen on adopting some characteristics of her native culture while embracing main aspects of the mainstream culture, 
and building relations with the host residents (1128). According to Berry, those who follow the strategy of integration feel less tension, and attain better resilience (1130). Isabel's correlation to her trumpet and the clave, an asymmetrical rhythm in the Cuban music, shows her capability of engagement with both Cuban and American cultures. Since the outset of the narrative, she is unable to hear the rhythm of clave, still when she perceives the sound of her trumpet playing in her motherland. During her journey, she is anxious that "she had never been able to count clave, but she had always assumed it would come to her eventually. That the rhythm of her homeland would one day whisper its secrets to her soul" (Gratz, Refugee 102). Nevertheless, her worrying over hearing clave intensifies when she reaches the U.S.A. When Isabel enrolled in the school, Uncle Guillermo gives her a trumpet as a gift. Joining the school band, she plays a salsa version of the American nationalized anthem and finally becomes able to count the clave rhythm. Thus, her "departure does not completely separate [her] either from the society to which [she] originally belonged or from the one [she] joins" (van Gennep 37). Her successful integration and resilience is symbolized by her playing of the U.S. national anthem on her Cuban-version trumpet. In this way, Isabel returns to "her new, relatively stable, well-defined position in the total society" where she is fully integrated and becomes proud of being an American citizen (Turner, "Liminal to Liminoid" 57). 
As for Mahmoud, his rite of incorporation first occurs when he is warmly welcomed by the German Government that takes him and his family to a temporally cozy hostel designed for refugees. Moreover, when Mahmoud and his family come to meet the host family, "cries of joy and welcome came from the porch ... His mother was being hugged by an elderly German woman, and an elderly German man was shaking hands with his father (Gratz, Refugee 311-312). According to van Gennep such "various forms of greetings ... fall into the category of rites of incorporation" (32-33). In spite of the cultural distance between the two families, Mahmoud achieves successful adaptation and resilience. Berry assures that the most essential motivation that encourages immigrants' successful adaptation and resilience is the attitude adopted by the member the host group (1124). Mahmoud feels that he is "incorporated into the group that most closely corresponds to his own character," because the host German woman has a history of being a refugee like him (van Gennep 35). In fact, this woman happens to be Ruthie, Josef's sister who is the only one of her family who survives the Holocaust. Mahmoud senses that "such hospitality gives [him] ... political rights" (van Gennep 35) and that Germany and Ruthie's home seem 'like a home" (Gratz, Refugee 317). Consequently, he is "prepared for a whole series of changes in the nature of the cultural and ecological activities to be undertaken and of the relationships [he] will then have with others"(Turner, "Liminal to Liminoid" 57). 
The family becomes a legal resident of this new country where they are given the living know-how of the place and initiate a new life.

\section{Conclusion}

The aim of this paper is to provide a comprehensive analysis on the various phases of the journey of the refugee protagonists as reflected in Alan Gratz's Refugee. The anthropological theory, rites of passage, is used to provide a different perspective on how to view and understand the journey of the three refugee protagonists through the different phases that trigger a significant life-change: pre-liminal (departure), liminal (in-transit), and postliminal (arrival). In the pre-liminal phase, the three refugee protagonists experience the departure from homelands and thereby also a departure from an earlier version of themselves. During the liminal phase, on the other hand, the protagonists find themselves trapped between a failing protection regime and the rules of non-place. They are looked upon as illegal subjects who try to transgress borders. In the post liminal phase, only Mahmoud and Isabel successfully reach and reintegrate into the receiving society. Josef, unfortunately, remains suspended in the intermediary phase. Moreover, by integrating the theoretical concepts of non-place and resilience as an extension to rites of passage, the spatial as well as psychological aspects of the protagonists experience are fully explored. They pinpoints the 
challenges that they have to overcome in order to continue their journey and move from the non-place zone of non-belonging to a place where they are fully recognized as legal citizens. 


\section{Works Cited}

Augé, Marc. Non-Places: An Introduction to Supermodernity. Translated by John Howe, Verso, 1995.

Berry, John W. "Intercultural Relations in Plural Societies: Research Derived from Multiculturalism Policy." Acta de Investigacion PsicologIca, vol. 3, no. 2, 2013, pp. 1122 - 1135. revistapsicologia, doi:10.1016/S2007-4719(13)70956-6. Accessed 22 Aug. 2021.

Bhugra, Dinesh. "Migration, Distress and Cultural Identity." Historical and Geographical Perspectives on Health and Illness, vol. 69, no.1, 2004, pp. 129-141. British Medical Bulletin, doi:10.1093/bmb/ldh007. Accessed 14 April 2021.

Birkholm, Molly. Building Your Resilience: Finding Meaning in Adversity. The Teaching Company, 2019.

Bowie, Fiona. The Anthropology of Religion: An Introduction. Blackwell, 2006.

Cresswell, Tim. "Place." International Encyclopedia of Human Geography, edited by Nigel Thrift and Rob Kitchen, Elsevier, vol. 8, 2009, pp. 169-177.

Gratz, Alan. “About Me." Alan Gratz, 2021, https://www.alangratz.com/about/. Accessed 21 Aug. 2021.

Gratz, Alan. Refugee. Scholaristic Press, 2017. 
Lazarus, Richard S., and Susan Folkman. Stress, Appraisal and Coping. Springer Publisher, 1984.

Mlambo, Nelson. Trauma, Resilience and Survival Strategies in Crisis Times: An Afrocentric Literary Approach. Scholar's Press, 2014.

Moore, Catherine. "Resilience Theory: What Research Articles in Psychology Teach Us." Positivepsychology, 19 Mar. 2021, https://positivepsychology.com/resilience-theory/. Accessed 22 June. 2021.

Neenan, Michael. Developing Resilience: A Cognitive Behavioral Approach. Routledge, 2018.

Sharma, Sarah. "Baring Life and Lifestyle in the Nonplace." Cultural Studies, vol. 23, no. 1, Jan. 2009, pp. 129-148. Taylor \& Francis. doi: 10.1080/09502380802016246. Accessed 31 Aug. 2021.

Szakolczai, Arpad. Reflexive Historical Sociology. Routledge, 2000.

The American Psychological Association. "Building Your Resilience.” APA, 1 Jan. 2012, https://www.apa.org/topics/resilience. Accessed 1 June. 2021.

Thomassen, Bjørn. Liminality and the Modern: Living Through the InBetween. Routledge, 2014.

---. "The Uses and Meaning of Liminality." International Political Anthropology, vol. 2, no. 1, Mar. 2009, pp. 5-28. Political 
Anthropology, http //www.politicalanthropology.org/. Accessed 31 Aug. 2021.

Turner, Victor. "Liminal to Liminoid, in Play, Flow, and Ritual: An Essay in Comparative Symbology." Rice Institute PamphletRice University Studies, vol. 60, no. 3, 1974, pp. 53-92. Rice Scholarship, https://scholarship.rice.edu/handle/1911/6315 Accessed 4 April. 2021.

---. The Forest of Symbols: Aspects of Ndembu Ritual, Cornell University Press, 1967.

---. The Ritual Process: Structure and Anti-Structure, Cornell University Press, 1969.

Tusaie, Kathleen, and Janyce Dyer. "Resilience: A Historical Review of the Construct." Holistic Nursing Practice, vol. 18, no. 1, 2004, pp. 3-8. National Library of Medicine, doi: 10.1097/00004650-200401000-00002. Accessed 31 Aug. 2021.

Van Gennep, Arnold. The Rites of Passage. Translated by Monica Vizedom and Gabrielle Caffee, Routledge, 1960. 